
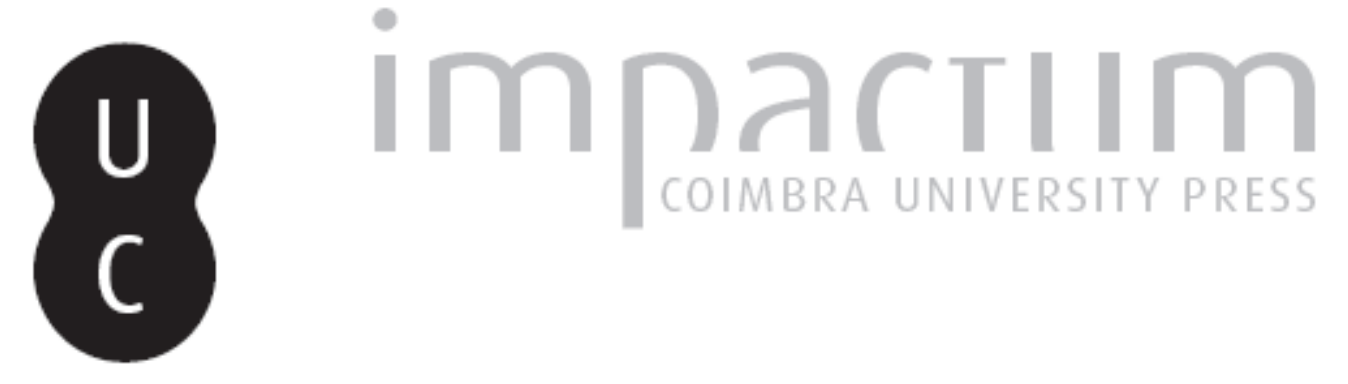

\title{
A relação pedagógico-amorosa no contexto teognídeo
}

\author{
Autor(es): Onelley, Glória Braga
}

Publicado por: Centro de História da Universidade de Lisboa

URL persistente:

URI:http://hdl.handle.net/10316.2/33001

DOI:

DOI:http://dx.doi.org/10.14195/0871-9527_22_8

Accessed : $\quad$ 26-Apr-2023 11:01:49

A navegação consulta e descarregamento dos títulos inseridos nas Bibliotecas Digitais UC Digitalis, UC Pombalina e UC Impactum, pressupõem a aceitação plena e sem reservas dos Termos e Condições de Uso destas Bibliotecas Digitais, disponíveis em https://digitalis.uc.pt/pt-pt/termos.

Conforme exposto nos referidos Termos e Condições de Uso, o descarregamento de títulos de acesso restrito requer uma licença válida de autorização devendo o utilizador aceder ao(s) documento(s) a partir de um endereço de IP da instituição detentora da supramencionada licença.

Ao utilizador é apenas permitido o descarregamento para uso pessoal, pelo que o emprego do(s) título(s) descarregado(s) para outro fim, designadamente comercial, carece de autorização do respetivo autor ou editor da obra.

Na medida em que todas as obras da UC Digitalis se encontram protegidas pelo Código do Direito de Autor e Direitos Conexos e demais legislação aplicável, toda a cópia, parcial ou total, deste documento, nos casos em que é legalmente admitida, deverá conter ou fazer-se acompanhar por este aviso.

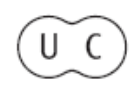



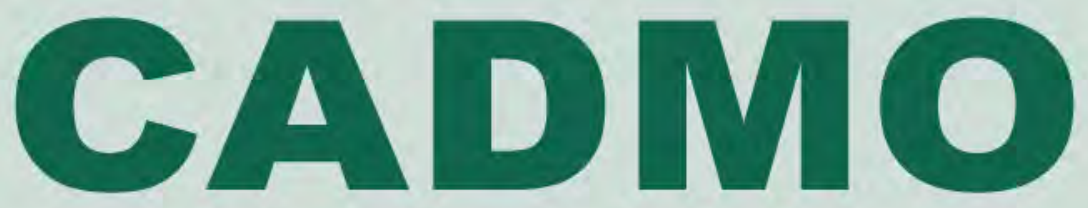

Revista de História Antiga

\author{
Centro de História \\ da Universidade de Lisboa
}

\title{
22
}

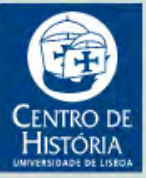

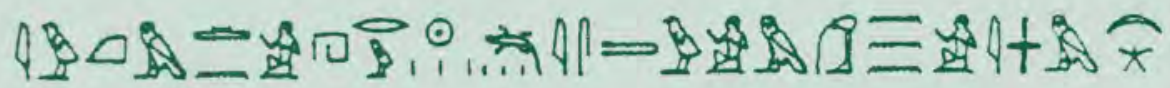

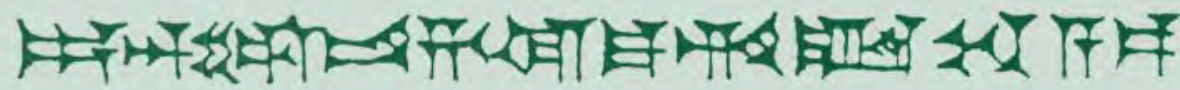
MHNIN AEI $\Delta \mathrm{E} \Theta \mathrm{EA} \Pi \mathrm{\Pi H} \Lambda \mathrm{HIA} \Delta \mathrm{E} \Omega$ 


\title{
A RELAÇÃO PEDAGÓGICO-AMOROSA NO CONTEXTO TEOGNÍDEO
}

\author{
GLÓRIA BRAGA ONELLEY \\ Universidade Federal Fluminense \\ gloriaonelley@terra.com.br
}

\section{Resumo}

Atribui-se a Teógnis de Mégara, poeta que floresceu possivelmente em meados do século VI a. C., uma coletânea de elegias conhecida como Corpus Theognideum. É esse Corpus composto de, aproximadamente, 1400 versos, de temática e extensão bastante variadas, alguns dos quais imputados a outros elegíacos, como Tirteu, Mimnermo, Sólon e Eveno de Paros, e, ainda, a poetas anônimos. A despeito da controvertida questão acerca da autenticidade da coletânea teognídea, ressalte-se que ela representa um relevante testemunho literário, ainda que não autobiográfico, para o conhecimento de diferentes aspectos da sociedade grega aristocrática do período arcaico, em cujo seio se instituiu a prática da pederastia. Com base na análise de versos do Corpus Theognideum, propomo-nos mostrar que a pederastia se apresenta ora como um instrumento pedagógico para preservação dos princípios aristocráticos, ora como um sentimento mais íntimo e erótico entre um homem mais velho e um jovem.

Palavras-chave: Corpus Theognideum; paideia; pederastia.

\section{Abstract}

It is attributed to Theognis of Megara, poet that flourished probably around the $6^{\text {th }}$ century b. C., an elegies compilation known as Corpus Theognideum. This Corpus is composed by nearly 1400 verses of theme and extension quite diverse, some of which imputed to other elegiac 
poets, like Tyrtaeus, Mimnermus, Solon and Euenus of Paros and, yet, anonymous poets. In spite the controversial question about the authenticity of the theognidean compilation, it must be pointed out that it represents a relevant literary testimonial, although not autobiographic, to the knowledge of different aspects of the archaic period aristocratic greek society, in whose middle pederastic practice has been estabilished. Based on the Corpus Theognideum verses analysis, we propose to show that pederasty presents itself sometimes as a pedagogic instrument for the preservation of the aristocratic principles, and sometimes as a much more intimate and erotic between an old man and a young.

Key-words: Corpus Theognideum; paideia; pederasty.

O presente estudo versa sobre a relação pedagógico-amorosa no Corpus Theognideum, coletânea de elegias atribuída, embora não exclusivamente, a Teógnis de Mégara, poeta elegíaco que floresceu possivelmente em meados do século VI a. C. (c. 544-541)1, em Mégara Niseia, segundo a maior parte da crítica moderna.

É essa coletânea de elegias composta de 1389 versos, distribuídos em um livro de 1230 versos, de temática e extensão bastante variadas, muitos dos quais têm como eixo temático a decadente situação política e econômica da classe aristocrática, que se viu privada da riqueza e, por conseguinte, do poder político, em virtude do surgimento de uma nova classe, procedente de estratos não aristocráticos, que, a partir do século VII a. C., ascendeu ao poder, destruindo, na maioria das cidades gregas, a antiga ordem aristocrática. Assim, entre outros tópoi da poesia grega arcaica, como a brevidade da juventude e a aproximação da morte, a exortação a beber e a agir moderadamente, predominam nesse Livro I versos elegíacos que privilegiam como tema a vida política da pólis, dividida em duas classes antagônicas - agathoí versus kakoí -, as consequências dos conflitos de classes, como o confisco de riquezas, o exílio e a pobreza dos nobres, o contraste entre a excelência dos verdadeiramente nobres e a conduta ignóbil dos não aristocratas e, ainda, a amizade partidária, a philía, como um relevante veículo de manutenção e transmissão do ideário aristocrático.

Esses 1230 versos, que compõem o chamado Livro I, são seguidos de um conjunto menor de fragmentos de temática amorosa, sobretudo amoroso-pederástica, conhecido como Livro II. É ele composto de 84 dísticos, preservados no mais antigo manuscrito, Manuscrito A, Parisinus supl. gr. 388, datado do século X, porém só conhecido no século XIX, quando, por volta de 1800 , foi levado para Paris. 
Para Massimo Vetta (1980, pp. XI-XIII), esse apêndice erótico data do século VI a. C. ${ }^{2}$ e talvez tenha sido obra de um compilador que, "com reservas morais», entre 850 e os primeiros decênios do século $\mathrm{X}$, teria retirado de um corpus unitário ${ }^{3}$ as elegias de «inspiração» pederástica.

Nessa segunda parte da obra, que, sublinha Dover (1994, p. 25), constitui o mais importante acervo de poesia homossexual anterior ao período helenístico, encontram-se, em tese, declarações amorosas a um jovem, em geral anônimo ${ }^{4}$, designado pelo vocativo ô pai, «ó jovem, ó menino" - fórmula considerada marca distintiva dos poemas amorosos, afirmam Carrière (1946, p. 113, nota 4) e Massimo Vetta (1980, p. 50) -, reflexões pessimistas, ameaças e censuras da persona masculina e adulta, ou seja, do erastés, diante do comportamento leviano e inconstante do jovem amado que, ressalta Dover (1994, p. 34), «já atingira a altura de adulto», como atesta a iconografia erótica dos períodos arcaico e clássico, com base na qual o helenista estudou a homossexualidade masculina na Grécia.

É importante assinalar, entretanto, a presença, também no Livro I, de elegias de tom amoroso-pederásticas, muito embora não sejam elas assinaladas pela apóstrofe efébica ó pai. São elas, segundo Massimo Vetta (1980, p. XIII), as compreendidas entre os versos 371-2; 951-4; 959-62; 1017-22; 1063-8; 1091-4; 1095-6; 1097-1100 e, talvez, 993-6.

Por outro lado, também no Livro II, há versos que, segundo Dover (1994, p. 87), podem ser associados ao amor homossexual ou heterossexual, ou, na opinião de Massimo Vetta (1980, p. XIII), integrar um corpus «purificado». Mencionam ambos os helenistas as elegias compreendidas entre os versos $1231-4 ; 1275-8 ; 1323-6$ e 1386-9. As duas primeiras referem-se a Éros como uma força geradora do mal e do bem, respectivamente:

Terrível Eros, as Manias, tendo-se apoderado de ti, amamentaram-te; por tua causa, pereceu a cidade de Ílion, pereceu também o grande Teseu, filho de Egeu e, ainda, o valoroso Ájax, filho de Oileu, por causa de teu orgulho insensato.

(Corpus Theognideum, vv. 1231-4)

O Amor nasce na época oportuna, justamente no momento em que a terra fecunda se cobre de folhas primaveris;

então Eros, tendo deixado Chipre, a belíssima ilha, partirá em direção aos homens, levando o sêmen sobre a terra.

(Corpus Theognideum, vv. 1275-8) 
Expressa-se, na primeira elegia, o Amor como completa loucura, desvario e, por conseguinte, aniquilamento, já que, devido ao binômio Érōs/loucura, cujas raízes se perdem no passado mitológico da Grécia, heróis foram ao encontro da morte. Revela esta prece ao deus que, em virtude do amor desenfreado incitado por Érōs, sucumbiram a cidade de ílion, por causa do amor desmedido de Páris por Helena, o herói Teseu, pela tentativa de ajudar Pirítoo a raptar Perséfone - uma ameaça direta às fronteiras entre os vivos e os mortos - e também Ájax, ao que parece pela violação da sacerdotisa Cassandra, no templo de Palas Atena, em Troia ${ }^{5}$. Tendo, pois, inspirado os mortais a transgredir a ordem divina, Erōs é considerado skhlétios, "cruel» (v. 1231), não somente pelo fato de causar sofrimento às suas vítimas, mas também por impeli-las a cometer atos cruéis e impiedosos, semelhantes aos seus próprios. De fato, como bem observou Massimo Vetta (1980, p.40), o ponto comum dos três exemplos míticos evocados é a asébeia, «impiedade», inspirada por Érōs e depois punida com a morte. Digna de nota é também a relação Érōs/loucura, assinalada pela imagem do aleitamento da divindade pelas Maníai, causadoras dessas catástrofes amorosas.

Convém observar que os paradigmas míticos destacados para acentuar o ânimo cruel de Érōs se referem a amores por mulheres e não por meninos. Portanto, esta invocação ao deus do Amor não deve constituir o prólogo do Livro II dos Theognidea, como pretenderam os defensores da unidade da coletânea, nem se referir, como conjecturou Dover (1994, p. 87), «tanto ao eros homossexual quanto ao heterossexual», em virtude de o tom e o conteúdo da invocação ao deus não se harmonizarem com a temática amorosa delineada nesse apêndice erótico.

Com efeito, a constatação do poder destruidor de Érōs, em 1231-4, contrasta com a descrição de sua chegada à Terra, no início da primavera, em 1275-8. Nestes dísticos, de acentuada inspiração lírica, a voz do poema, ao fazer uma reflexão acerca da alegria que Érōs desperta no coração dos homens, ressalta a função do deus do amor como responsável pela fecundidade, pela vida e sua manutenção na Terra, em oposição aos versos 1231-4, nos quais Érōs é o causador da morte.

Quanto aos dísticos 1323-6 e 1386-9, constituem eles uma prece à deusa Afrodite, inspiradora da beleza e do amor arrebatador, a quem a persona dos primeiros versos citados solicita a libertação dos sofrimentos causados pela ardente paixão. A respeito desses sofrimentos, Massimo Vetta (1980, pp. 102-3) afirma serem eles de natureza eróticos, já que a destinatária da súplica é a deusa regente do amor. 
Na segunda elegia, a persona, ao interpelar a deusa, ratifica a impossibilidade de o homem livrar-se de seu invencível poder, bem marcado pelo epíteto dolóploke ${ }^{6}$, «tecelã de astúcias, astuciosa» (v. 1386) - em cuja primeira parte, dolo-, está implícita a ideia de dolo, engano, astúcia e, na segunda, plóke-, derivada de plékō, a de tecer e, metaforicamente, a de tramar -, mas também pela forma verbal damnâis «submetes pela força, dominas» (v. 1388), a qual indica a violência com a qual o amor domina o ânimo.

Ó Ciprogênia, afasta-me dos sofrimentos, dissipa as preocupações que devoram meu coração e fá-lo voltar de novo à alegria;

faz cessar as funestas inquietudes, e concede-me, com teu coração propício, depois de ter eu vencido a pujança da juventude, as obras da temperança.

(Corpus Theognideum, vv. 1323-6)

Ó Ciprogênia, astuciosa deusa de Citera, que coisa magnífica Zeus, para te honrar, te deu para que possuísses este dom?

Dominas o espírito prudente dos homens, e ninguém é tão forte e tão sábio que saiba evitar-te.

(Corpus Theognideum, vv. 1386-9)

Registram-se, ainda, no Livro II, elegias de cunho político-social, que centram seu eixo temático na amizade/inimizade e na lealdade/traição e, por conseguinte, em conselhos e advertências para a escolha correta de amizades. À guisa de exemplo, citam-se os dísticos 1238a-b, 1239-40, $1243-4,1245-6$ e 1247-8, dos quais se pode destacar o primeiro, cuja temática se harmoniza com as elegias de tom sociopolítico, presentes no Livro I.

Depois de teres abandonado o que está a teu lado, jamais procures outro amigo,

confiando nas palavras de homens inferiores.

(Corpus Theognideum, 1238a-b)

Vale destacar que dos 1389 versos dos Theognidea somente um pequeno corpus é imputado pela maioria dos helenistas modernos ao poeta Teógnis de Mégara. Posicionamentos vários e divergentes têm sido dados à questão da autenticidade da obra, quer pelos partidários da unidade da coletânea, quer pela maioria da crítica moderna, defensora de ser o Corpus Theognideum um acervo de composições poéticas procedente de variadas mãos. 
A despeito das controvertidas questões suscitadas acerca da autenticidade da coletânea, cumpre ressaltar que ela, além de representar uma valiosa fonte para o conhecimento da elegia pré-alexandrina, constitui um valioso testemunho literário, ainda que não autobiográfico, para o conhecimento de diferentes e relevantes aspectos da sociedade grega aristocrática do período arcaico, dos quais se destacou, no presente trabalho, o amor pederástico, isto é, o amor de um homem adulto, o erastés, «amante», por um menino, um paîs, o parceiro passivo da relação homoerótica, ou seja, o erómenos, a quem era vedado o prazer sexual, deste só podendo desfrutar o erastés, o parceiro ativo, ressalta Bremmer (1995, p. 21). Tratava-se, segundo Adrados (1995, p. 52) e Bremmer (1995, p. 22) de uma relação unilateral. A esse respeito salienta Dover (1994, p. 80):

Em termos claros, o que é que um eromenos recebe em troca da submissão a seu erastes? A resposta grega convencional é de que não deriva nenhum prazer corporal (cf. Pl. Fdr. 240d); e que se isto ocorrer, ele passará a ser criticado como pornos e pervertido.

Quanto à origem da pederastia, também Dover (op. cit., p. 254) assinala que, embora atualmente haja consenso de ser ela oriunda da organização militar dos estados dórios, de modo que sua propagação pelo mundo grego é atribuída à influência dórica, é difícil precisar o momento e o lugar em que se estabeleceu essa prática homoerótica (op. cit., p. 264). Para o helenista, a origem dórica não explica a «velocidade e o entusiasmo com o qual os não dóricos adotaram estas práticas» (op. cit. p. 264).

Com efeito, a par das imagens pintadas em vasos áticos da segunda metade do século VI a. C., que registram, segundo Dover (1994, p. 268), cenas de cortejo homossexual (ibidem, p. 136 sqq.), as mais antigas referências poéticas ao amor pederástico não são, de acordo com o referido helenista, de origem dórica. Para ele, embora Alceu de Mitilene seja reconhecido como poeta cultor de paidiká, a julgar pelos testemunhos de Cícero (Tusculanas, IV, 71) e Horácio (Odes I, 32, 9-11), nenhum de seus fragmentos remanescentes comprova «esta generalização» 7 .

Acrescenta, então, Dover (1994, p. 268) que «a expressão mais antiga do eros homossexual na poesia» se encontra no fragmento 25 West do poeta ateniense Sólon, em que a voz do fragmento se expressou assim:

Quando na amável flor da juventude ele ama um menino, desejando suas coxas e sua doce boca.

(Sólon, fr. 25W) 
No fragmento em questão, o amor pelo menino pode ser depreendido não só pelo emprego da forma verbal paidophilésēi ${ }^{8}$, mas também por elementos reveladores da sensualidade do jovem, como as coxas e a doce boca.

Assim, ainda que no fragmento de Sólon o amor descrito não seja idealizado, mas esteja voltado para os prazeres sensuais, é importante assinalar que essa tradição, certamente aristocrática, de paideía pederástica era totalmente distinta da homossexualidade, sublinham Adrados (1995, p. 52) e Bremmer (1995, p. 26), já que não consistia na prática de relações sexuais entre o adulto e o jovem, mas visava, sobretudo, à educação deste último, que era iniciado nas atividades políticas e sociais do erastés, seu modelo e mentor espiritual. Era, portanto, o homem mais velho o responsável pela formação do caráter e da personalidade do jovem amado, cuja educação se efetivava por meio da pederastia. Não se quer dizer com isso que desse relacionamento não pudesse surgir um envolvimento amoroso. Acerca da intimidade na relação entre o adulto e o jovem, merecem destaque as observações de Adrados (1995, pp. 102-4), segundo o qual não havia na relação pederástica indício algum de homossexualismo, tendo em vista não haver cópula anal. Na verdade, o objeto de desejo do erastés, esclarece o helenista, eram as coxas do menino, nas quais o amante vertia seu sêmen. Vale citar as considerações de Dover (1994, p. 141) a respeito da reciprocidade amorosa entre o adulto e o menino:

Quando o cortejar foi bem-sucedido, erastes e eromenos ficam em pé, um de frente para o outro; o erastes agarra o eromenos pelo torso, abaixa a cabeça até o ombro do eromenos - ou mesmo mais abaixo -, dobra os joelhos e enfia seu pênis entre as coxas do eromenos, bem abaixo dos testículos (...). A diferença de estatura é considerável, e o homem precisa colocar as suas pernas semiflexionadas (sic) por fora das do menino.

Atestam-no também o fragmento de Sólon e as pinturas de vasos áticos do século $\mathrm{VI}$ a. C., nas quais a ilustração mais frequente, afirma também Dover (1994, p. 136), é aquela em que o homem mais velho acaricia com uma das mãos o rosto do adolescente e, com a outra, sua genitália.

Destarte, era por meio dos laços existentes entre o adulto e o jovem que se realizava um dos mais tradicionais processos de transmissão dos valores aristocráticos. É essa forma de amor viril, como método pedagó- 
gico, que transparece em dísticos vários dos Theognidea, revelando-se o éros/paideía ora sob a forma de sentimentos mais puros e paternais, que visavam ao aperfeiçoamento intelectual e social do amado, e não apenas ao prazer sexual do homem mais velho, ora sob a forma de manifestações mais apaixonadas e eróticas.

Quanto ao aspecto educativo do relacionamento pederástico, W. Jaeger (1989, p. 166) afirma que a relação afetiva entre o amante e o amado podia ser comparável «à autoridade educadora dos pais em relação aos filhos». Significativo a esse respeito é o dístico 1351-2 em que a persona, identificada como um homem mais velho, aconselha 0 mais novo, nos seguintes termos:

Ó jovem, não saias às ruas para festejar, obedece a um homem já velho; na verdade, não fica bem a um jovem sair às ruas para festejar.

(Corpus Theognideum, vv. 1351-2)

Ressalte-se que o imperativo de peíthomai, peítheo, «obedece», empregado no verso 1351, parece corroborar a postura paternal do homem mais velho e experiente que visa ao bem e ao aperfeiçoamento moral da pessoa amada. Acresce, ainda, que a iteração do verbo komázein, derivado de kômos e aqui traduzido por "sair às ruas para festejar» - também empregado em outros versos do corpus na acepção de «frequentar banquetes» (vv. 886 e 1065) -, parece ter no dístico em questão um sentido negativo, denotando os aspectos orgiásticos do kômos, parte final dos banquetes em que os convivas completamente embriagados percorriam as ruas com músicas, cantos e danças, numa alegria e liberdade excessivas, comportamento contrário ao ideal de obediência à ordem e à medida, tão encarecido pela aristocracia grega.

Quanto à ocasião de performance desse fragmento, Massimo Vetta (1980, p. 124) aventa a hipótese de ter sido ele executado no momento em que o néos estava prestes a sair do simpósio para participar do kômos.

Aliás, o banquete podia ser um ambiente propício ao surgimento da relação entre erastés e erómenos. Nos versos 993-6, ao interpelar um certo Academo - talvez um personagem-tipo, entre outros que figuram no Corpus Theognideum -, a persona poética demonstra que se podia disputar como prêmio (âthlon) a atenção de um menino, em concursos realizados durante o banquete, ocasião em que a prova de um doce canto desempatava os rivais, constituindo-se o prêmio na mais estimulante recompensa após a vitória. Dirigindo-se a Academo, a voz masculina diz: 
Se pusesses a concurso, Academo, entoar um doce canto, e se no meio de nós dois, que disputamos em habilidade, houvesse como prêmio, para mim e para ti, um jovem na bela flor da juventude, saberias como as mulas são mais fortes que os asnos.

(Corpus Theognideum, vv. 993-6)

Ainda que a tônica desses versos seja, como conjectura Massimo Vetta (1980, p. XIII, nota 3), a disputa acerca da habilidade musical, sugerem eles, segundo van Groningen (1966, p. 373), uma conotação erótica, já que um menino aparece como prêmio de um concurso musical.

No entanto, a presença de meninos e adolescentes não estava circunscrita a ambientes simpóticos. O encontro entre o amado e o amante podia ocorrer nos ginásios e nas palestras ${ }^{9}$, onde os meninos, completamente nus, se exercitavam sob os olhares de seus admiradores mais velhos.

O dístico 1353-6

Feliz aquele que, apaixonado, se exercita no ginásio para, de volta à casa, dormir o dia todo com um belo jovem.

(Corpus Theognideum, vv. 1353-6)

parece corroborar a ideia de que o ginásio e a palestra propiciavam o encontro amoroso, tendo em vista que, após o exercício corporal (gymnázetai, v. 1335), o amante poderia, ao voltar para casa, deleitar-se com um kalôi paidí, «um belo jovem», que observara durante a prática de exercícios gímnicos.

A duração do relacionamento amoroso estava condicionada ao aparecimento de pelos na face do jovem. Tratava-se, observa Bremmer (1995, p. 21) - pelo menos no que diz respeito à cidade de Atenas da segunda metade do século VI a. C. -, de uma ligação afetiva transitória, ligada à idade, como atesta a declaração do amante ao jovem paîs:

Ó jovem, enquanto tiveres a face lisa, jamais deixarei de te elogiar, nem mesmo se fosse meu destino morrer.

Para ti que te entregas é ainda honroso, mas para mim, que te amo, não é suplicar. Mas eu te imploro, por nossos pais:

vergonhoso tem piedade de mim, ó jovem, <> dando-me gratidão, se é que algum dia tu também

terás, se desejares, o dom de Afrodite, coroada de violetas, e irás para junto de um outro (jovem); pois bem, pelo menos que a deusa te permita receber em troca as mesmas palavras.

(Corpus Theognideum, vv. 1327-34) 
Note-se que a expressão leían gényn, «face lisa» (v. 1327), característica de um jovem ainda imberbe, determina a fase de atuação amorosa do menino. Entretanto, se o relacionamento pederástico ultrapassasse o período de adolescência do amado, ressalta Buffière (1980, p. 7), esse princípio ideológico de educação aristocrática convertia-se em homossexualismo. Similarmente, também Dover (1994, p. 277) se refere à reprovação, em qualquer comunidade grega, da relação erótica entre amante e amado, após a fase de adolescência deste último, bem como a inaceitabilidade de um envolvimento homoerótico entre pessoas da mesma idade.

Cabe salientar, ainda, o argumento usado pela persona para sensibilizar o jovem a entregar-se aos prazeres de Afrodite, qual seja, a fugacidade da juventude - lugar-comum nos poetas arcaicos. Assim, o amante rejeitado lembra ao jovem que um dia, depois de passar à condição de erastés, será ele a suplicar a kháris (v. 1331), "gratidão», do amado e será a deusa regente de éros a impor-Ihe a retaliação.

Vale notar, ainda, que o relacionamento pederástico não impedia que o homem mais velho tivesse pelo sexo oposto uma admiração apreciável, como se infere do dístico 1225-6, em que a voz masculina tece elogios a uma boa esposa:

Nada é mais doce, Cirno, que uma boa esposa!

Eu sou testemunha disso, e tu sê de minha verdade.

(Corpus Theognideum, vv. 1225-6)

Com base nos dísticos citados, verifica-se que a ligação com um paîs - relação institucionalizada como um rito de iniciação do jovem na sociedade masculina - e o casamento não eram, de modo algum, incompatíveis, pois a primeira visava, como método pedagógico por excelência, ao aprimoramento intelectual e social do amado, e o segundo, à procriação e, consequentemente, à preservação das linhagens. Observa Adrados (1995, p. 103) que "se tratava de uma homossexualidade juvenil muito especial, logo substituída pela heterossexualidade do homem mais velho".

Convém lembrar que o aspecto educativo da pederastia delineia-se em passagens várias do Corpus Theognideum, sobretudo nos versos em que a persona poética - que alguns helenistas identificam com a pessoa do poeta ${ }^{10}$ - dirigindo-se a Cirno ${ }^{11}$, desejava transmitir-Ihe os princípios tradicionais aristocráticos, sintetizados no seguinte dístico: 
A ti, por considerar-te, ensinarei precisamente aquilo que eu mesmo, Cirno, ainda criança, aprendi dos homens de bem.

(Corpus Theognideum, vv. 27-8)

Julgando-se, portanto, detentor de uma sabedoria herdada, transmitida pelos agathoí - termo que nos Theognidea designa a classe aristocrática -, a voz masculina - egò autós «eu mesmo» (v. 27) - assume o papel de mentor de Cirno. Para Groningen (1966, p. 22), o verbo hypothésomai, "ensinarei" (v. 27), resume o conteúdo da obra de Teógnis, aquele que a Suda (II, 13) mencionou nos seguintes termos: «ele compôs ... para Cirno .. uma gnomologia em dísticos elegíacos».

Entretanto, Cirno parece não ser somente o erómenos a quem a persona desejava educar segundo os princípios da aristocracia, mas também o destinatário passivo de confissões e de lamentos amargurados do porta-voz da nobreza, que se dá conta de ter a sociedade perdido sua essência e estar sendo levada pela corrente de novos ideários, distintos de seus próprios. Nos versos 833-6, isentando os deuses de qualquer responsabilidade pelas desgraças advindas aos homens, a voz do poema revela que a antiga ordem aristocrática estava destruída e corrompida, graças à violência, à atração fatal por ganhos ilícitos e à insolência, marcas distintivas, no Corpus Theognideum, dos adversários políticos da nobreza ${ }^{12}$.

Tudo está abandonado aos corvos e à ruína; para nós, Cirno, nenhum dos deuses bem-aventurados é o responsável, mas a violência, os ganhos vergonhosos e a desmedida precipitaram-nos da opulência na miséria.

(Corpus Theognideum, vv. 833-6)

Vale salientar que se na maioria das elegias dirigidas a Cirno o paidikòs éros - o amor por um menino - traduz um sentimento mais moral e pedagógico, em outras passagens dos Theognidea - mormente em dísticos do chamado Livro II, um genuíno código de amor por meninos -, o relacionamento pederástico transpõe qualquer preocupação pedagógica e converte-se numa ligação mais íntima entre erastés e erómenos, predominando nessa relação a indiferença e a infidelidade amorosa deste último e, em consequência, a censura e o repúdio do amante diante do descaso e da traição do jovem.

Com efeito, censuras, invectivas e reflexões pessimistas acerca do caráter inconstante e leviano do paîs podem ser observadas em passa- 
gens várias do Livro II, entre as quais se podem citar os versos 1249-52 e 1267-70, nos quais o jovem é comparado a um animal/símbolo da beleza e do vigor erótico, ou seja, a um cavalo que, saciado de cevada, ora retorna à casa do bom cavaleiro, ou seja, à morada de seu primeiro amante, ora o despreza, acolhendo um outro prazerosamente.

Ó jovem, tal como um cavalo, após te fartares de cevada, tu voltaste à minha morada,

desejando um bom cavaleiro, um belo prado, uma fonte fresca e bosques umbrosos.

(Corpus Theognideum, vv. 1249-52)

Um jovem e um cavalo possuem o mesmo feitio: pois um cavalo não chora seu cavaleiro que jaz na poeira,

mas leva o homem que Ihe sucedeu, se estiver saciado de cevada; assim também o jovem ama o que está presente.

(Corpus Theognideum, vv. 1267-70)

Ressalte-se que, para Massimo Vetta (1980, p. 56), o sintagma oracional epei krithôn ekorésthes, "após te fartares de cevada», presente no verso 1249 e repetido no verso 1269, sob a forma krithaîsi korestheís, "se estiver saciado de cevada», exerce uma função metafórica, indicando o grau de traição do erómenos que, em 1249-52, após usufruir das vantagens de outros parceiros, volta à casa de seu primeiro amante, porque este lhe oferece «a philia melhor». Para Dover (1994, p. 88), esse mesmo sintagma alude à cópula, opinião refutada por Massimo Vetta (ibidem), segundo o qual o substantivo krithé, «cevada», indicando o órgão genital masculino, só é usado na comédia ática do século $\mathrm{V}$ a. $\mathrm{C}$. Note-se, ainda, que a expressão heníokhon ... agathón «bom cavaleiro» (v. 1251) acena para a ideia de reconhecimento, por parte do erómenos, das qualidades sensuais de seu amante e representa, como bem observou Massimo Vetta (1980, p. 57), um típico caso de autoexaltação em poesia erótica, concretizada por meio da imagem do locus amoenus, que se traduz na descrição de elementos da natureza, consentâneos à relação homoerótica - um belo prado, uma fonte fresca e bosques umbrosos (vv. 1251-2). Assinala, ainda, o helenista estar nos versos 1251-2 a primeira ocorrência, na literatura grega, da expressão do locus amoenus num contexto metafórico, emprego que ultrapassa sua esfera de simples elemento descritivo.

Embora se possa discutir sobre os sentimentos vários que o amor por um menino fazia desabrochar no erastés - paixão, ódio, repúdio, vingança -, pôde-se observar, com base em alguns versos do Corpus Theogni- 
deum, uma sensível diferença nas manifestações do éros pederástico: em alguns, visa ele à preservação do sistema de valores da nobreza; em outros, sob a capa da pederastia pedagógica, ultrapassa esse contexto e vem acompanhado de uma ardente e incontida paixão que tinge, com um colorido especial, a pederastia aristocrática.

\section{Notas:}

Todas as traduções são de responsabilidade da autora do presente artigo.

(1) Três são as possíveis datas acerca da época em que teria vivido o poeta Teógnis: a primeira, defendida por Martin West (1974, pp. 68-70), situa a akmé do poeta na segunda metade do século VII a. C.; a segunda e a terceira datam Teógnis nos séculos VI e V a. C., segundo a interpretação dada pelos estudiosos ao termo gegonós da Suda, empregado ora na acepção de «nascido», ora na de «florescido».

(2) Massimo Vetta (1980, pp. XI-XII) justifica a datação, considerando o testemunho do Lexicon Suda, segundo o qual as elegias amorosas figuravam no mesmo corpus que as de cunho parenético - «Teógnis compôs parêneses, mas, no meio delas, estão disseminadas muitas impurezas, amores por meninos e outras que a vida virtuosa desvia» -, e, ainda, as correspondências existentes entre as elegias do Livro I, em particular as consideradas autênticas, e as do Livro $\mathrm{II}$, quanto ao léxico, às estruturas de composição, aos motivos referentes ao aprimoramento do jovem adolescente e aos destinatários.

(3) Sobre esta procedência do Livro II também estão de acordo Carrière (1946, p. 85, nota 1) e Martin West (1974, p. 43 sqq.). Para este último, afirma Dover (1994, p. 25), a separação das elegias de cunho predominantemente pederástico da obra de Teógnis talvez tenha ocorrido no início da Idade Média, «quando as sensibilidades ficaram chocadas pela justaposição de extravagantes expressões de emoção homossexual com severas exortações à honestidade e sinceridade».

(4) Segundo Massimo Vetta (1980, p. XLIII), o anonimato do jovem amado possibilitava a execução do material poético por parte de qualquer integrante do simpósisio.

(5) Para as versões míticas acerca da morte de Teseu e da de Ájax, ver Massimo Vetta (1980, pp. 39-42).

(6) O epíteto dolóploke tem sua primeira ocorrência no fragmento 1 LP (v. 2) da poetisa Safo.

(7) Posição contrária apresenta Massimo Vetta (1982, p. 7-10) que considera de tom pederástico três lacunares fragmentos do poeta de Mitilene, quais sejam: o fragmento 296 (b) Voigt, «um dos textos mais problemáticos de Alceu» (pp. 10-1) e os fragmentos 366 e 368 Voigt (p. 7, nota 1, e p. 8). Aliás, para as composições de temática pederástica, é preciso considerar, segundo Vetta (1980, pp. XXXVII e XXXVIII), as duas modalidades poéticas distintas, a elegíaca e a lírica. Para esta última, o representante mais antigo de paidiká é, afirma Vetta, Estesícoro (c. 612-29 a. C.), cuja fonte é Ateneu (XIV, 601a).

(8) Dover (1994, p. 77) e Adrados (1995, p. 30) afirmam ser usual a substituição do termo paiderastés e do verbo paiderástein por paidophíles e paidophílein, respectivamente, já que os dois primeiros termos não se ajustam ao metro elegíaco.

(9) O ginásio era o local onde os meninos e os homens adultos faziam exercícios gímnicos, parte essencial da educação grega. A palestra era o lugar onde os jovens recebiam instrução em 
luta livre e ginástica, podendo fazer parte do ginásio ou ser um local separado. A palestra como lugar para a prática da pederastia é bem conhecida no século $V$ a. C., como atestam passos das comédias de Aristófanes (Nuvens, 973 sqq.; Aves, 139 sqq.) e dos diálogos de Platão (cf. Dover, 1994, pp. 83-5)

(10) Com base no testemunho da Suda (vol. II, 13, p. 692), segundo o qual Cirno era o erómenos de Teógnis - «ele compôs... para Cirno, o seu erómenos, uma gnomologia em dísticos elegíacos...» - alguns helenistas (Carrière [1946], Groningen [1966], Burn [1960], Bowra [1969], entre outros) fazem uma abordagem biográfica dos versos que registram a apóstrofe ó Kýrne, identificando a pessoa do poeta com a persona de seus versos.

(11) A crítica moderna admite como provavelmente autênticos os versos elegíacos marcados pelo emprego dos vocativos Kýrne (ou sua variante Polypaíde), Cirno e Polipaides. Segundo Groningen (1966, p. 18), por exemplo, Cirno era o jovem aristocrata, filho de Polipaides, a quem Teógnis «dirigia conselhos práticos e morais e suas lástimas».

(12) No Corpus Theognideum, a oposição semântica entre os termos agathós/esthlós e kakós/ deilós - leitmotiv das elegias de tom sociopolítico - tende a permanecer vinculada, respectivamente, à classe dos aristocratas e à dos não aristocratas, muito embora o par kakós/deilós não caracterize apenas o homem de baixa estirpe, mas qualquer indivíduo não obstante sua nobreza de nascimento, que esteja em desacordo com o comportamento ético e político estabelecido pela aristocracia. Ademais, esses pares antagônicos denotam, no léxico dos Theognidea, não só categorias políticas e sociais, mas também morais, já que a eles se associam, respectivamente, como ressaltou Cobb-Stevens (1985, p. 92), justiça/desmedida, moderação/saciedade, excelência/vileza (cf. vv. 153-4, 279-82, 465-6, 611-4, 693-4, 1171-6).

\section{Referências bibliográficas}

ADKINS, A. W. H., Poetic craft in the early greek elegists, Chicago, London: The University of Chicago Press, 1985, 133-60.

ADRADOS, F.R., Sociedad, amor y poesía en la Grecia antigua, Madrid: Alianza Editorial, 1995.

BREMMER, J.N., «Pederastia grega e homossexualismo moderno", in De Safo a Sade: momentos na história da sexualidade. Tradução C. K. Moreira. Campinas: Papirus, 1995, 11-26.

BRILLANTE, C. «Charis, bia et il tema della reciprocità amorosa», QUCC 59, 1998 a, 7-34.

BUFFIĖRE, F., Eros adolescent - La pédérastie dans la Grèce antique, Paris: Les Belles Lettres, 1980, 49-63.

CARRIÈRE, J., Théognis de Mégare, Étude sur le recueil élégiaque attribué a ce poète, Paris: Bordas, 1946.

DONLAN, W., «Pistos Philos Hetairos», in Theognis of Megara Poetry and the polis, Baltimore, London: The Johns Hopkins University Press, 1985, 223-224.

DOVER, K.J., A Homossexualidade na Grécia Antiga, /Greek Homosexuality./ Tradução de Luís S. Krausz, São Paulo: Nova Alexandria, 1994.

FRÄNKEL, H., Early greek poetry and philosophy, London: Alden Press, 1975, 399-425.

IAMBI ET ELEGI GRAECI ANTE ALEXANDRUM CANTATI. Edidit M. L. West. 2nd. edition, London: Oxford University Press, 1989, v. I/ 1992. v. II. 
JAEGER, W., Paideia, a formação do homem grego. / Paideia, Die Formung Des Griechischen Menschen. / Tradução de Artur M. Parreira. $2^{a}$ ed., São Paulo: Martins Fontes, 1989, 159-185.

KNOX, B. M. W., «Teognis», in Easterling \& Knox (ed.), Historia de la literatura clásica, Cambridge University, V. I, Literatura griega (versión española de Frederico Zaragoza Alberick), Madrid: Gredos, 1990, 155-166.

LEWIS, J.M. «Eros and the polis in Theognis Book II», in Theognis of Megara. Poetry and the polis, Baltimore, London: The Johns Hopkins Press, 1985, 197-222.

LíRICOS GRIEGOS. ELEGÍACOS Y YAMBÓGRAFOS ARCAICOS (Siglos VII-V a. C.). Texto traduzido por Francisco R. Adrados. Madrid: Alma Mater, 1959-1981. v. II. / 1990. v. I.

PEREIRA, M. H. R., «Amizade, amor e Eros na "líada"», Humanitas 45, 1993, 3-16.

SUIDAE LEXICON. Edidit Ada Adler. Stuttgart: Teubner, 1971.

TARKOV, T.A., «Theognis 237-54: a reexamination», QUCC 29, 1977, 99-114.

THÉOGNIS, Poèmes élegiaques, Texte établi et traduit accompagné d'un commentaire par Jean Carrière, Paris: Les Belles Lettres, 1948, 2 éd., 1975.

VAN DER VALK, M.H.A.L.V., Théognis. Humanitas 4-5, 68-140, 1955-1956.

VAN GRONINGEN, B.A., Le premier livre édité avec un commentaire, Amsterdam: N. V. NoordHollandsche Uitgevers Maastschappij, 1966.

VETTA, M.P.S., «Teognide 1231-4 e Apolonio Rodio», RFIC 100 (3), 1972, 283-94. Elegiarum Liber Secundus, Roma: Edizioni dell' Ateneo, 1980. «ll P. Oxy. 2506 fr. 77 y la poesia perotica de Alceo», QUCC, 10, 1982, 7-20.

WEST, M.L., Studies in greek elegy and iambus. Berlin, New York: Walter de Gruyter, 1974, 40-71. 